
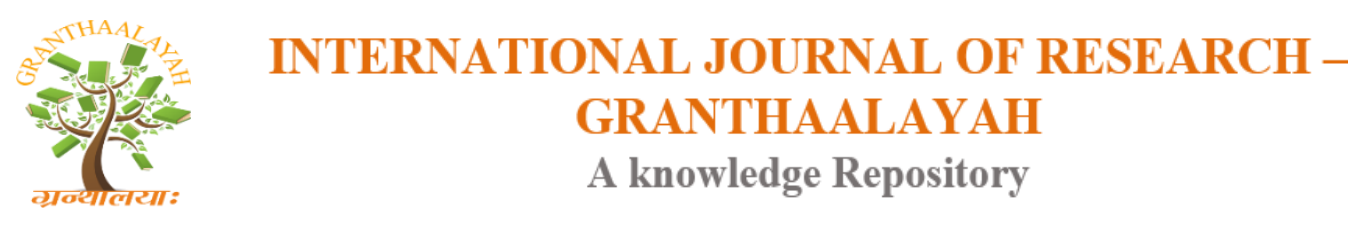

Management

\title{
RESIDENTS' ATTITUDE TO SOLID WASTE MANAGEMENT IN SELECTED QUARTERS IN OWO, ONDO STATE, NIGERIA
}

\author{
Tpl. Famakinwa Lawrecno Akin ${ }^{1}$, Tpl. Odogiyon Agunloye ${ }^{2}$ \\ ${ }^{1,2}$ Department of Urban and Regional Planning, Faculty of Environmental Studies, Rufus Giwa \\ Polytechnic, P.M. B 1019, Owo, Ondo State, Nigeria
}

\begin{abstract}
This work appraised residents attitude to domestic solid waste management in selected quarters in Owo, Ondo State, Nigeria. It identified types of domestic solid waste generated and examined the residents' perception of waste management at the three selected quarters in Owo which include Rufus Giwa Polytechnic Area, GRA and Iloro Quarters. Data were obtained directly from the targeted population using structured questionnaire and personal observations. The questions provided in the questionnaire were directed to the household population in the area. Meanwhile, photography was used for on-the-spot assessment of the conditions of some domestic solid waste spots in the study area. For the purpose of this research, systematic random sampling technique was adopted in the administration of questionnaire on residents of the three selected quarters in Owo, Ondo State. The univariate techniques of data analysis in form of tables, and photographs which describes the necessary features of the data set. Larger percentage of the respondents emptied their receptacles when it is filled. The research recommended that the federal government of Nigeria should partner with International Development Agencies to improve domestic solid waste management in the area.
\end{abstract}

Keywords: Solid Waste; Attitude; Receptacles; Management.

Cite This Article: Tpl. Famakinwa Lawrecno Akin, and Tpl. Odogiyon Agunloye. (2018). “RESIDENTS' ATTITUDE TO SOLID WASTE MANAGEMENT IN SELECTED QUARTERS IN OWO, ONDO STATE, NIGERIA.” International Journal of Research - Granthaalayah, 6(9), 96-104. https://doi.org/10.5281/zenodo.1436769.

\section{Introduction}

The United States Environmental Protection Agency (USEPA, 1971) defines solid waste as any garbage, refuse or sludge from a waste water treatment plant, water supply treatment plant or airdeed materials, including solid, liquid, semi-solid or contaminated gaseous materials resulting from industrial, commercial, mining and agricultural operations and from community activities.

Omosulu et al (2013) observed that, one of the salient environmental problems ravaging the world today is the problems of waste generation, collection and disposal. They also affirmed that the 
problems have attained a phenomenal dimension to the extent that it has become almost impossible to deal with it especially in the cities of the developing nations.

Hornby (1995) says that attitude is the way people behave towards something or issues, which shows how they think and feel about that thing.

People need to appreciate the fact that our environment is a delicate substance which could be negatively affected by environmental pollution. These pollutants are substances that are present naturally in our environment but when carelessly released in significant amount by humans becomes toxic (careless waste disposal methods is one of these pollutants) consequently, the task of protecting the environment is not a regional issue, neither is it a continental affair, but individual attitudes towards its management.

Owo, the headquarters of Owo local government area in Ondo State, and the traditional head of Owo kingdom, is an urban centre which has since 1980s been engulfed in waste management problems. The advent of the polytechnic Owo (now Rufus Giwa Polytechnic), Federal Medical centre (FMC) Owo, JOF Ideal Family farm and other notable corporate organizations enhanced growth and development in the town. The scale of domestic solid waste problems has become a source of worry and a monumental embarrassment to both the resident and indigenous population.

World Mayor, (2010) as cited by Omosulu et al (2013), infer that the waste situation is becoming even more frightening, as the Nigerian urban population is predicted to increase by between $2.20 \%$ and $2.40 \%$ the average for Kaduna and Ibadan from 2006 to 2020. In like manner Owo, being the headquarters of Owo Local government area, will equally increase both in population and land use. Arising from this prediction, this study focused on the attitude of the residents in the management of domestic solid waste in Owo town.

\section{The Study Area}

Owo is a city in Ondo State of Nigeria between 1400 and 1600 AD it was the capital of a Yoruba city state. Owo has an estimated population of 148,873 (projected from national population census of 1991).

Owo is located on latitude $7^{0} 11^{\prime} 0^{\prime}$ North of the equator, and on longitude $5^{0} 35^{\prime} 0^{\prime \prime}$ east of the Greenwich meridian. It is situated in South Western Nigeria at the Southern edge of the Yoruba hills and at the intersection of roads from Akure, Kabba, Benin City.

The present day city is an agricultural center involved in the growing and trade of yams, cassava, maize, okra, pepper, cocoa and cotton. There are however other meaningful industrial activities in the town including but not limited to timber and sawmilling, soya beans processing plant and block making industries. The town is dotted with branches of some of the foremost banks like, First Banks Plc, Wema Bank Plc., Skye Bank Plc. Eco Bank Plc. Heritage Bank Plc. and Zenith Bank Plc. The city is now witnessing a dramatic change due to expansion of its road network, particularly dualization of the main road beginning from Otapete and matched with a new ultra-modern market at the township. 


\section{Literature Review}

USEPA, (1971) affirmed that, storing waste properly while awaiting collection is of utmost importance to prevent unsightliness or attracts rats and flies. They also said that, in the advanced countries of the world where there exist effective and efficient urban solid waste management system, local government is responsible for defining and enforcing waste storage standards. They stated further that, it is however the responsibilities of the home owners to supply enough containers for waste generated and keep them in good condition. They posited further that, in many developing countries no laid down standards for the provision of solid waste storage receptacles exist. As a result, all sorts of containers were used. This practice does not only constitute health hazards to both the generators and waste management system, it also causes unsightliness.

Olawande, (1983) posited that materials to be used as household solid waste storage should be durable, light, properly water tight, resistant to corrosion, of adequate capacity, easy to clean and with fly-proof cover. And that it has to be of adequate capacity depending on the three important factors which include; the number of people to use it, method of refuse collection; that is, whether to be carried by children, adult or by local government (manually or mechanically), and the periods between collection and emptying.

USEPA, (1971) noted that, various types of household solid waste storage receptacles include: cans (metal or plastic), sacks (paper or plastic), mobile detachable containers, pit storage. And that in the less developed world, while residents store waste, the receptacles used are not adequately documented. Responsible for this may be the fact that no by-laws exist on standards for household waste receptacle.

Henry, (2005) inferred that the residents' socio-economic status is a good determinant of whether a household will be able to afford and willing to purchase a desired receptacle. He further stated that the culture of people also play an important role as this may hinder the acceptability of using modern containers. He concluded that where waste is not properly stored, both soil and water may be polluted from the leachate produced. The leachate is the contaminated liquid draining from decomposing waste. It can be from one or all of liquid from the waste, seepage from groundwater, and water from precipitation and surface runoff percolating through the refuse.

\section{Methodology}

This study focuses mainly on residents' attitude to domestic solid waste management in selected quarters in Owo, Ondo State, Nigeria.

The study embraces both primary and secondary sources of information. These were obtained from the field through the use of research instrument, such as administration of questionnaires, Secondary information was collected from reports, (published and unpublished sources), textbooks, journals, file of government agencies and parastatals. These include the National Population Commission, The local government, and Internet, among many others.

Three residential zones were selected for the research based on some parameters that are common in influencing people's attitudes. G.R.A is the home of elites in Owo where most of the residents 
were tenants whose landlords/landladies live abroad. Rufus Giwa Polytechnic area is an academic environment where majority of the residents were students of the institution who always vacate their residents after their two years programmes in the institution and may not return to reside there again. Iloro quarters is tacked the home of the indigenes. Most of the people who reside in Iloro were born and brought up there and they were not ready to go and reside any where soon.

There were four hundred and forty (440) plots in G.R.A, Ijebu Owo (Ondo State Ministry of Lands and Housing, Town Planning Division Akure, 1988). Although not all of these plots were developed as only three hundred and eighty seven (387) residential buildings were developed and occupied, (Authors' reconnaissance survey, 2017). Iloro quarters Owo, has an estimated one thousand eight hundred and six (1806) residential buildings. (Authors' reconnaissance Survey, 2017). Rufus Giwa Polytechnic Area has an estimated one thousand three hundred and twenty three (1323) residential buildings (Authors' reconnaissance Survey, 2017).

The residential buildings in the selected quarters are G.R.A (387), Rufus Giwa Polytechnic Area (1323) and Iloro (1806). Adebiyi (2006) affirmed that the larger the size the smaller the percentage to be sampled. Hence, the research adopted the ratio 2:2:10 formations, which means two percent $(2 \%)$ of the residential buildings in Iloro (1806) amount to 36, and two percent (2\%) of those in Rufus Giwa polytechnic Area (1323) amount to 27 and ten percent (10\%) of those in G.R.A is 39 (table 1). For this research a sample size of one hundred and two (102) was chosen. Essentially, there are traits of homogeneity in habitability in each of these selected quarters. Therefore, the proportion of the residential buildings considered as the sample size is quite plausible. This research adopts multi-stage sampling technique in the research procedure.

First stage is the delineation of the study area, and ascertains the boundaries of each quarter (Authors' reconnaissance, 2017).

Second stage is the identification of the buildings in each of the quarters by adopting systematic sampling technique. All buildings in each quarter were numbered serially, from which the sampled buildings were selected. The $10^{\text {th }}$ building in G.R.A forms the $n$th term, the $49^{\text {th }}$ residential building in Rufus Giwa Polytechnic area forms the nth term and the $50^{\text {th }}$ residential building in Iloro quarters forms the nth term. Purposive sampling technique was adopted in the third stage for the selection of respondents. The questionnaire was administered on any matured person who could confidently provide answers to the questions raised, in the selected residential building.

\section{Research Findings}

The research variables considered in this study focus on the attitude of residents in some selected quarters in Owo town, Ondo State, Nigeria. The types of domestic solid waste generated in the study area, socio economic characteristics of respondents in the study area which comprises of education qualification, and household income per month, respondents' perceptions about open dump spot in their area, and respondents interest on improved domestic waste management in the study area. 


\subsection{Domestic Solid Waste Generated in Owo}

Majority (46.5\%), of the respondents in Owo declared that they generate all of these waste which includes; food waste/biscuits wrapper, paper and plastics, cans and bottles, $27.3 \%$ of the respondents said they generate only food waste/biscuits wrapper and paper/plastics. $23.2 \%$ of them said they generate only food waste/biscuits wrappers, while $3 \%$ of the respondents said they generate only cans/bottles (Table 1).

However, the above pattern of results, varies from one location to another, (Table 1) at Rufus Giwa Polytechnic area, $40.8 \%$ of the respondents generate all the above types of waste. $29.6 \%$ of them affirmed that they generate food waste/biscuits wrappers. $22.2 \%$ of the household respondents in Rufus Giwa Polytechnic area generate both food waste/biscuits wrappers and paper/plastics. While, $7.4 \%$ of them generate cans/bottles.

From the same table 1, it could be deduced that, 50\% of the respondents in G.R.A generate all the types of domestic solid waste mentioned earlier. $33.3 \%$ of them generate food waste/biscuits wrappers and papers/plastics, but $13.9 \%$ generate only food waste/biscuits wrappers. Specifically only $2.8 \%$ of them generate cans/bottles.

$42.2 \%$ of household respondents in Iloro quarters revealed that they generate all the types of domestic solid waste earlier mentioned in this study. $27.8 \%$ of them said they generate food waste/biscuits wrappers only in their homes. $25 \%$ of them said they generate both food waste/biscuits wrappers and papers/plastics (table 1).

Table 1: Types of Domestic Solid Waste in Owo.

\begin{tabular}{|l|l|l|l|l|l|l|l|l|}
\hline \multirow{2}{*}{ Type of Waste } & \multicolumn{2}{c|}{ Rufus Giwa Area } & \multicolumn{2}{c|}{ G.R.A } & \multicolumn{2}{c|}{ Iloro Quarters } & \multicolumn{2}{c|}{ Total } \\
\cline { 2 - 10 } & Freq. & $\%$ & Freq. & $\%$ & Freq. & $\%$ & Freq. & $\%$ \\
\hline Food waste/biscuit & 8 & 29.6 & 5 & 13.9 & 10 & 27.8 & 23 & 23.2 \\
\hline Paper/plastic & - & - & - & - & - & - & - & - \\
\hline Can/bottle & 2 & 7.4 & 1 & 2.8 & - & - & 3 & 3.0 \\
\hline A \& B & 6 & 22.2 & 12 & 33.3 & 9 & 25.0 & 27 & 27.3 \\
\hline All of the above & 11 & 40.8 & 18 & 50.0 & 17 & 42.2 & 46 & 46.5 \\
\hline Total & 27 & 100 & 36 & 100 & 36 & 100 & 99 & 100 \\
\hline
\end{tabular}

Source: Author's field survey, 2017

\subsection{Respondents' Perceptions About Open Dump Spot in Their Areas}

Analysis of the problems associated with open dump spots in this research is borne out of the conviction that the long term sustainability of domestic solid waste management in the area could only be guaranteed, if the respondents' view of the ways they perceive the problems are determined.

Gauging respondents' perceptions about the open dump spot in their area, $44.4 \%$ of the respondents affirmed that they were always deeply disturbed whenever they were close to the open dump spot, $25.3 \%$ of them said there is no open dump spot in their areas, $18.2 \%$ of the respondents 
revealed that although they were always disturbed but not deeply disturbed, while $12.1 \%$ of them said they were less concern about open dump spot in their area (table 2).

This result varies from area to area, at Rufus Giwa Polytechnic area, 63\% of the respondents said they were deeply disturbed whenever they get close to the open dump site in their area, $18.5 \%$ of them revealed that they were less concern, $11.1 \%$ affirmed that they were always disturbed but not deeply disturbed and $7.4 \%$ of them said there was no open dump spot in their area. At G.R.A, $63.9 \%$ of the respondents disclosed that they do not have domestic solid waste dump spot in their area, $22.2 \%$ of them said they were always deeply disturbed, $13.9 \%$ said they were disturbed but not deeply disturbed. At Iloro quarters, $52.8 \%$ of the respondents revealed that they were always deeply disturbed, $27.8 \%$ of them said they were always disturbed but not deeply disturbed and $19.4 \%$ said they were less concern about domestic solid waste dump spot in their area (table 2).

A critical look at table 2 confirmed yet again the justification for selecting these study areas. G.R.A. being the resident of elites showed that majority (63.9\%) of the respondents does not have open dump spot in their area. This does not mean that they do not generate domestic solid waste but their proof of change of attitude has made them to manage their waste properly. The rest of them who had in their area said they were disturbed and deeply disturbed about it. This revelation is a confirmation of positive change of attitude may be due to their level of education or the conviction of residing in the area for a very long time to come, were of the opinion of keeping the environment clean for a better tomorrow (Sustainable Development), unlike Rufus Giwa Polytechnic area where the residents were of the opinion of just to reside for a short period and leave after their programmes. Majority (63\%) of them were deeply disturbed but less concerned because of their short stay in the area. The fact that the residents of Iloro quarters do not have change of attitude lead majority $(80.0 \%)$ of the respondents to revealed that they were disturbed and deeply disturbed but yet some (19.4\%) were less concerned.

Table 2: Respondents' Perception about open dump spot in their areas

\begin{tabular}{|l|l|l|l|l|l|l|l|l|}
\hline \multirow{2}{*}{ Feelings } & \multicolumn{2}{|c|}{ Rufus Giwa Area } & \multicolumn{2}{|c|}{ G.R.A } & \multicolumn{2}{c|}{ Iloro Quarters } & \multicolumn{2}{c|}{ Total } \\
\cline { 2 - 9 } & Freq. & $\%$ & Freq. & $\%$ & Freq. & $\%$ & Freq. & $\%$ \\
\hline Deeply disturbed & 17 & 63.0 & 8 & 22.2 & 19 & 52.8 & 44 & 44.4 \\
\hline Disturbed & 3 & 11.1 & 5 & 13.9 & 10 & 27.8 & 18 & 18.2 \\
\hline Less concern & 5 & 18.5 & - & - & 7 & 19.4 & 12 & 12.1 \\
\hline Non in my area & 2 & 7.4 & 23 & 63.9 & - & - & 25 & 25.3 \\
\hline Total & $\mathbf{2 7}$ & $\mathbf{1 0 0}$ & $\mathbf{3 6}$ & $\mathbf{1 0 0}$ & $\mathbf{3 6}$ & $\mathbf{1 0 0}$ & $\mathbf{9 9}$ & $\mathbf{1 0 0}$ \\
\hline
\end{tabular}

Source: Author's field survey, 2017 


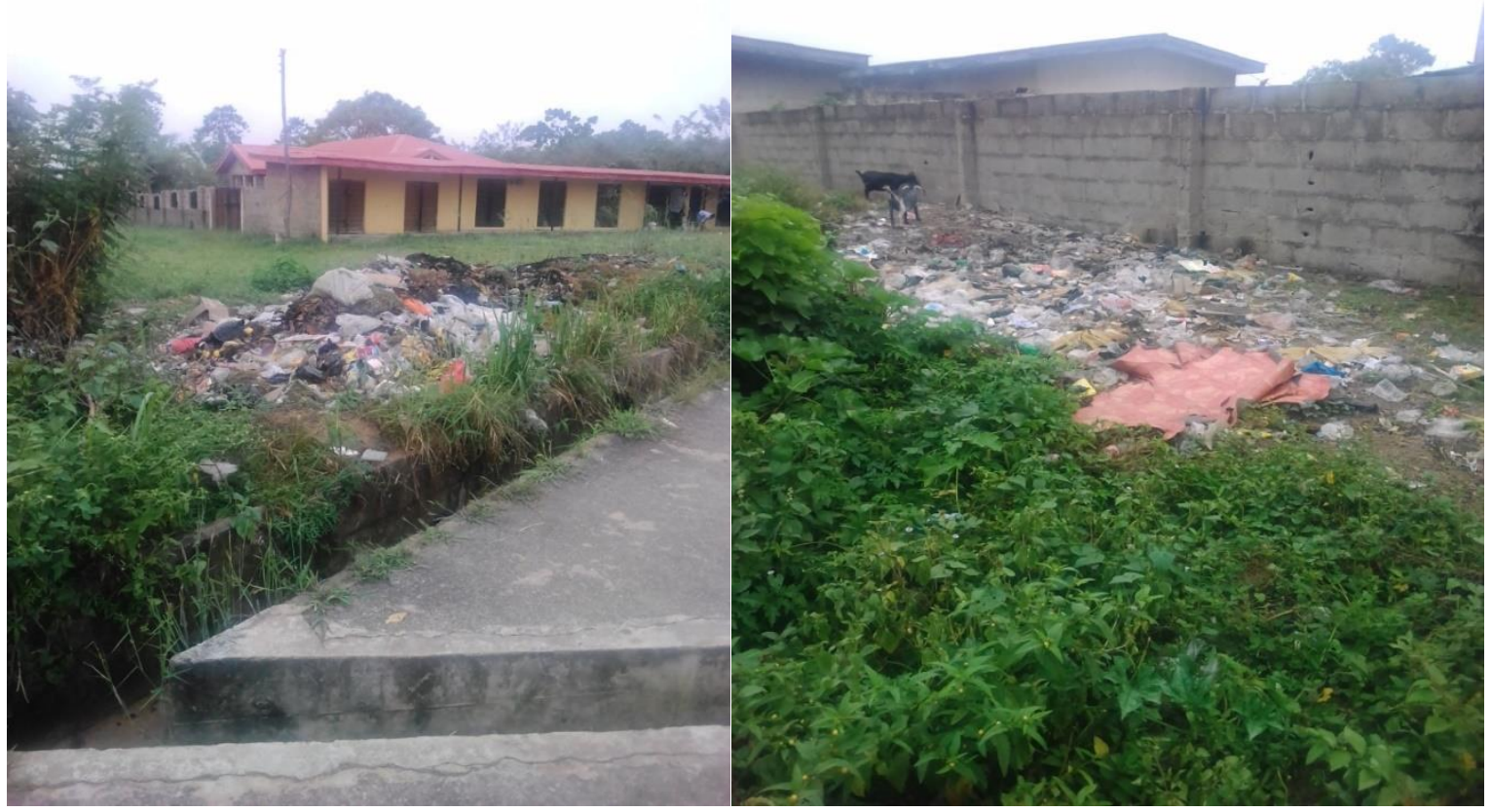

Plate 1: Shows some open dump spots in Iloro quarters, Owo.

\subsection{Respondents Interest on Improved Domestic Solid Waste Management in the Study Area}

Analysis of the level of interest on improved domestic solid waste management in this research is borne out of the conviction that the long term sustainability of the improved domestic solid waste management could only be guaranteed, if the people are willing to support the project. $46.1 \%$ of the respondents revealed that they are willing to support any project on improved domestic solid waste management, $42.4 \%$ are absolutely willing, while $11.1 \%$ of them said they are not willing (table 3).

At Rufus Giwa Polytechnic area, 51.9\% of the respondents disclosed that they were willing to support improved domestic solid waste management, $29.6 \%$ said they were absolutely willing, $18.5 \%$ said they were not willing. At G.R.A, $52.8 \%$ of the respondents said they were absolutely willing, $36.1 \%$ said they were willing, and $11.1 \%$ affirmed that they were not willing to support improved domestic solid waste management. At Iloro quarters, $52.7 \%$ of the respondents said they were willing to support improved domestic solid waste disposal in their area, $417 \%$ said they were absolutely willing, only $5.6 \%$ said they were not willing (table 3 ).

The inference that could be drawn out of this revelation is that improved domestic solid waste management in the study area could be sustained due to the fact that a whopping $88.9 \%$ of the respondents were willing to support the practice as against just $11.1 \%$. 
Table 3: Respondents Interest on Improved Domestic Solid Waste Management in the Study

\begin{tabular}{|l|l|l|l|l|l|l|l|l|}
\hline \multicolumn{1}{|c|}{ Interest } & \multicolumn{1}{|c|}{ Rufus Giwa Area } & \multicolumn{2}{c|}{ G.R.A } & \multicolumn{2}{c|}{ Iloro Quarters } & \multicolumn{2}{c|}{ Total } \\
\cline { 2 - 10 } & \multicolumn{1}{|c|}{ Freq. } & $\%$ & Freq. & $\%$ & Freq. & $\%$ & Freq. & $\%$ \\
\hline Absolutely Willing & 8 & 29.9 & 19 & 52.8 & 15 & 41.7 & 42 & 42.4 \\
\hline Willing & 14 & 51.9 & 13 & 36.1 & 19 & 52.7 & 46 & 46.5 \\
\hline Not Willing & 5 & 18.5 & 4 & 11.1 & 2 & 5.6 & 11 & 11.1 \\
\hline Total & 27 & 100 & 36 & 100 & 36 & 100 & 99 & 100 \\
\hline
\end{tabular}

Source: Author's Field Survey, 2017.

\section{Recommendations and Policy Guidelines}

This study has examined the attitude of residents to solid waste management in some selected quarters in Owo town, Ondo State, Nigeria. The following are some of the policy recommendations of the study.

- Waste management policy guidelines.

- Necessary policy guidelines at National, State, and Local government levels must be given adequate attention, to ensure compliance, through monitoring for sustainability.

- Education empowerment to residents.

- It is obvious from the survey carried out that education was among the underline factors to the residents' attitude to domestic solid waste management in selected quarters of Owo. In view of this, the research recommends that there should be a synergy between government and the stakeholders in Owo towards the programme, in order to boost their status and thereby improve on their perception on domestic sold waste management.

- Provision of financial backing to the residents of Owo. There should be synergy between the government and the residents of Owo by providing financial backing with no or little interest to boost their economic base, in order to enhance their income and thereby invest on improved domestic solid waste management in terms of multiplier effect.

- Enhancement of partnership with Federal Government and International Development Agencies to improve domestic solid waste management.

- Encourage community participation through socio-economic and religious groups on improved domestic solid waste management.

- Strengthening the role and enhancing the operational capacity of the domestic solid waste management and treatment infrastructure and personnel.

- Public Enlightenment Campaign.

\section{References}

[1] Adebiyi J.K (2006). Issues in Research, Biotidara Press and Computer, Akure, Ondo State.

[2] Henry, J.G. (2005). Solid Wastes in Henry J.G. and Heinke G.W. (Eds) Environmental Science and Engineering, New Delhi, Prentice Hall (Pp. 567 - 619).

[3] Hornby A.S., (1985). Oxford Advanced Learner's Dictionary, Oxford University Press, Oxford, New York.

[4] National Population Commission, (1991). Federal Republic of Nigeria. Abuja.

[5] Oluwande, P.A., (1983). A guide to tropical environmental health and engineering, Ibadan, NISER. 
[6] Omosulu S.B., Esheimokhai O.E., Adegbenro O.O, and Matt K.A., (2013). An Appraisal of solid Waste Management in Auchi, Edo State Nigeria (JEP \& D) Vol. 3 No 1. (pg. 24 - 35).

[7] USEPA, (United States Environmental Protection Agency (1971). Guidelines for Local Government in Solid Waste Management.

[8] World Mayor., (2010). The World Fastest Growing City and Urban Areas from 2006 to 2010. City Mayor Statistics retrieved on 11/17/2011.

*Corresponding author.

E-mail address: lawrecno@yahoo.com/ odogiyonagunloye@yahoo.com 